DOE/HTGR-86-005 ORNL/GCR-85/12
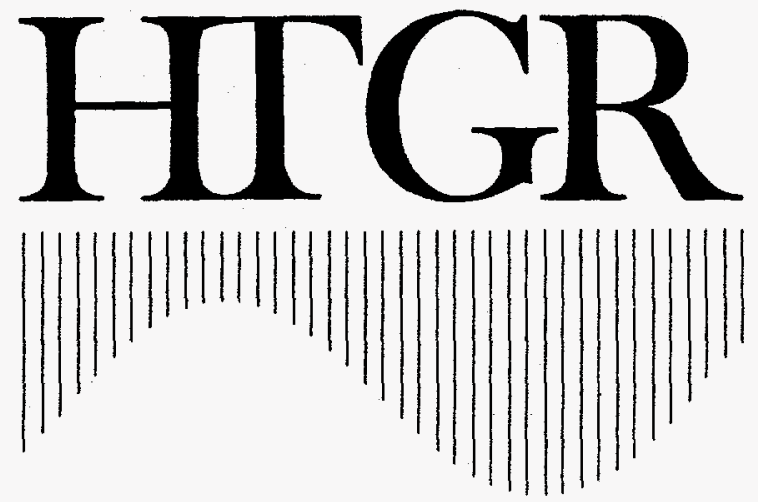

\title{
REPORT ON CHEMICAL IMPURITIES \\ IN LOTS OF 2020 GRAPHITE
}

\section{MASTER}

\section{AUTHORS/CONTRACTORS}

R. A. Strehlow, Oak Ridge National Laboratory

Oak Ridge National Laboratory

Oak Ridge, Tennessee 37831

operated by

MARTIN MARIETTA ENERGY SYSTEMS, INC.

for the

MASTER

UNITED STATES DEPARTMENT QEENERGY - . -

Novembar 1985

DISTRIBUTON OF THIS DDCUMENT is UNimite 


\section{DISCLAMMER}

Portions of this document may be illegible in electronic image products. Images are produced from the best available original document. 


\title{
DOE / HTGR-86-005 \\ ORNL/ GCR-85/12
}

Contract No. DE-AC05-840R 21400

OAR RIDGE NATIONAL LABORATORY

GAS-COOLED REACTOR PROGRAMS

HTGR BASE TECHNOLOGY PROGRAM

(Activity AF 212030 0)

Graphite Studies

(FTP/A HTR0100 WBS 1602.01)

[Milestone No. 1602.01.05 under WBS 1]

REPORT ON CHEMICAL IMPURITIES IN LOTS OF 2020 GRAPHITE

\author{
R. A. Strehlow \\ November 1985 \\ DISCLAIMER
}

\begin{abstract}
This report was prepared as an account of work sponsored by an agency of the United States Government. Neither the United States Government nor any agency thereof, nor any of their employees, makes any warranty, express or implied, or assumes any legal liability or responsibility for the accuracy, completeness, or usefulness of any information, apparatus, product, or process disclosed, or represents that its use would not infringe privately owned rights. Reference herein to any specific commercial product, process, or service by trade name, trademark, manufacturer, or otherwise does not necessarily constitute or imply its endorsement, recommendation, or favoring by the United States Government or any agency thereof. The views and opinions of authors expressed herein do not necessarily state or reflect those of the United States Government or any agency thereof.
\end{abstract}

OAK RIDGE NATIONAL LABORATORY

Oak Ridge, Tennessee 37831

operated by

MARTIN MARIETTA ENERGY SYSTEMS, INC.

for the

U.S. DEPARTMENT OF ENERGY 

ABSTRACT $\ldots \ldots \ldots \ldots \ldots \ldots \ldots \ldots \ldots \ldots \ldots \ldots \ldots \ldots \ldots \ldots \ldots \ldots \ldots \ldots \ldots \ldots \ldots \ldots \ldots . \ldots 1$

INTRODUCTION $\ldots \ldots \ldots \ldots \ldots \ldots \ldots \ldots \ldots \ldots \ldots \ldots \ldots \ldots \ldots \ldots \ldots \ldots \ldots \ldots \ldots \ldots \ldots$

METHODS AND RESULTS $\ldots \ldots \ldots \ldots \ldots \ldots \ldots \ldots \ldots \ldots \ldots \ldots \ldots \ldots \ldots \ldots \ldots \ldots \ldots \ldots$

DETECTION OF AGGLOMERATES $\ldots \ldots \ldots \ldots \ldots \ldots \ldots \ldots \ldots \ldots \ldots \ldots \ldots \ldots \ldots \ldots \ldots . \ldots . \ldots$

ISOLATION AND ANALYSIS OF AGGLOMERATES $\ldots \ldots \ldots \ldots \ldots \ldots \ldots \ldots \ldots \ldots \ldots$

HEAT TREATMENT STUdIES $\ldots \ldots \ldots \ldots \ldots \ldots \ldots \ldots \ldots \ldots \ldots \ldots \ldots \ldots \ldots \ldots \ldots \ldots \ldots$

DISCUSSION AND CONCLUSION $\ldots \ldots \ldots \ldots \ldots \ldots \ldots \ldots \ldots \ldots \ldots \ldots \ldots \ldots \ldots \ldots \ldots$

ACKNOWLEDGMENTS $\ldots \ldots \ldots \ldots \ldots \ldots \ldots \ldots \ldots \ldots \ldots \ldots \ldots \ldots \ldots \ldots \ldots \ldots \ldots \ldots \ldots$

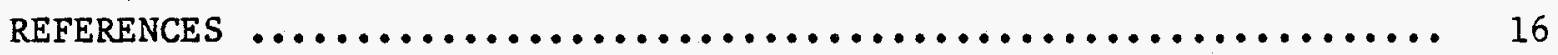




\section{R. A. Strehlow}

\section{ABSTRACT}

Chemical and physical studies on agglomerated and dispersed impurities found in three lots of 2020 graphite received from the Stackpole Company are described. Each lot consisted of three billets, one shipment of off-the-shelf 2020 and two of "nuclear quality" graphite for which efforts had been taken to decrease impurity levels.

An earlier report described the results of chemical analyses of the three lots of graphite and the gross distribution of the impurities in the billets. The present report describes the chemical and physical studies on the detailed distribution and chemical identity of the agglomerates that led to the identification of their source.

Agglomerated impurities were found in all lots of 2020. The particles possessed an average size range of about $0.3 \mathrm{~mm}$. In addition to these particulates, other inorganic ash forming components were found to be rather more uniformly distributed internally throughout the graphite.

\section{INTRODUCTION}

Stackpole 2020 graphite has been selected as the material of choice for several applications as a permanent component in the reference design gas-cooled reactor. 1

Three shipments (lots of 2020 graphite) were received at the Oak Ridge National Laboratory for tests and evaluation. Each of the lots consisted of three cylindrical billets measuring $\sim 180 \mathrm{~cm}$ long by $25 \mathrm{~cm}$ diam. The first lot was a standard or off-the-shelf 2020 graphite and was used in Test Zero of the Core Support Performance Test (SCPT) series. 2

The second and third shipments were the first iteration in the development of a nuclear quality material by the manufacturer. These two shipments were designated nuclear lot 1 and lot 2. 
It had been recognized earlier that stock or off-the-shelf 2020 graphite was not a satisfactory materlal for application as a permanent component in a gas-cooled reactor because of agglomerated impurities in the graphite and the variability of impurities from billet to billet.

The development plan involved the use of specially selected raw materials in order to avoid the agglomerated impurity problem and to use a higher graphitization temperature in order to decrease the billet-tobillet variability. Nuclear-quality lot 1 was found still to have agglomerated impurities, but only after nuclear lot 2 had already been committed. As a consequence, the differences between lots 1 and 2 were not great and a more detailed examination of the impurities was needed.

An earlier report described the sampling plan for the three shipments of 2020 graphite and the results of chemical analyses. 3 These analyses yielded data for the composition of impurities averaged over several cubic centimeters of graphite volume. Accordingly, only gross or large-scale variations were mapped. Because the agglomerates had sizes and probable variations on a submillimeter scale, physicochemical methods were invoked that would have the necessary sensitivity and precision.

\section{METHODS AND RESULTS}

DETECTION OF AGGLOMERATES

Agglomerate particles were detected by radiography of machined slab specimens that were routinely obtained in accordance with the sampling plan described earlier. ${ }^{4}$ The specimens were of thickness $0.250 \pm 0.005$ in. machined to an rms 250 microinch smoothness. This precision has been found adequate to permit the obtaining of high-quality radiographic images.

Sixty-nine radiographs were obtained of slab specimens adjacent to the regions from which samples for chemical analysis had been obtained. All of the radiographs for the three shipments showed agglomerated impurities. 
A correlation was sought between the number density and size range of the agglomerates and the chemical analysis of the adjoining graphite regions. A radial variation of size appeared in some specimens and the particle sizes varied over a range of $0.1 \mathrm{~mm}$ to almost $1.0 \mathrm{~mm}$. The radial correlation was not uniform from billet to billet. Skin effects near the surface of the billet were observed, with larger particles often tending to be $1-3 \mathrm{~cm}$ below the surface. Qualitatively, it appeared that a common size for the impurity agglomerates was about $0.3 \mathrm{~mm}$.

The number density of agglomerate particles was estimated for several of the specimens and fell in the range of 20 to more than 100 distinguishable particles per cubic cm. In general, the higher number densities were in regions of the specimen in which the particles were somewhat smaller and conversely. Specimens of the nuclear quality materials appeared to have the widest range of both size and number density as compared with the off-the-shelf graphite.

Because the off-the-shelf graphite appeared to have somewhat fewer and more uniformly sized particles, it appeared possible that the differences between it and lots 1 and 2 might be associated with lower calcium, and higher silicon and iron contents that were observed for the off-the-shelf material. 3

\section{ISOLATION AND ANALYSIS OF AGGLOMERATES}

Samples from some of the slab specimens were prepared for destructive examination in order to obtain isolated particles of the agglomerated impurities.

Portions of slab specimens were cut to provide 1/4-in,-thick pieces about $1 \mathrm{in.}$ by $6 \mathrm{in}$. In size, including the billet axis and the material along a radius to the circumference. Specimens of off-the-shelf material and of selected representative portions from lots 1 and 2 were used. These specimens were heated in air at $\sim 900^{\circ} \mathrm{C}$ for $16 \mathrm{~h}$ on heavy platinum foil. This procedure oxidized the graphite leaving an ash containing the inorganic impurities of the graphite in oxidized form. Since the ash 
largely remains in place during this oxidation, the result is an image of the original impurity locations and geometries. It should be noted that many of the inorganic impurities in graphite are expected to be in the form of carbides.

The ash pattern that was formed in this procedure was examined visually and portions were petrographically examined with a polarizing microscope.

The off-the-shelf graphite specimens had numerous regions of reddishbrown material with an extremely fine-grained structure and other regions of a white or cream-colored fine-grained structure, in which were observed particulates in the same size range as the agglomerates observed in the radiographic examination. Material from nuclear quality lots 1 and 2 showed no evidence of any colored material, but the appearance otherwise was similar to that of the off-the-shelf graphite.

Based on the chemical analyses, the coloring is probably iron. The colored material was found in various parts of the billets, sometimes being internal and sometimes near the cylindrical surface.

Petrographic examination of the ash showed no crystalline areas larger than $20 \mu \mathrm{m}$ or so. Most of the material was too small for petrographic study $(<1-2 \mu \mathrm{m})$. The larger particles were agglomerates of very finely divided material. This inhomogeneity has not yet been explained. In the off-the-shelf graphite, more particles were found in areas of higher iron content.

The particulates are shown in black and white copies of two color photographs, Figs. 1 and 2. Figure 1 shows the section of billet 148, section $C$, quadrant IV. This is from an interior section of one of the off-the-shelf billets. The agglomerated particles are readily seen and an estimate can be made of their distribution in the specimen.

Different specimens had differing amounts of agglomerated particulates and different distributions of colored material. There did not appear to be uniformity in the size, location, or distribution of the agglomerates. The fine grained matrix material ranged from fluffy to 


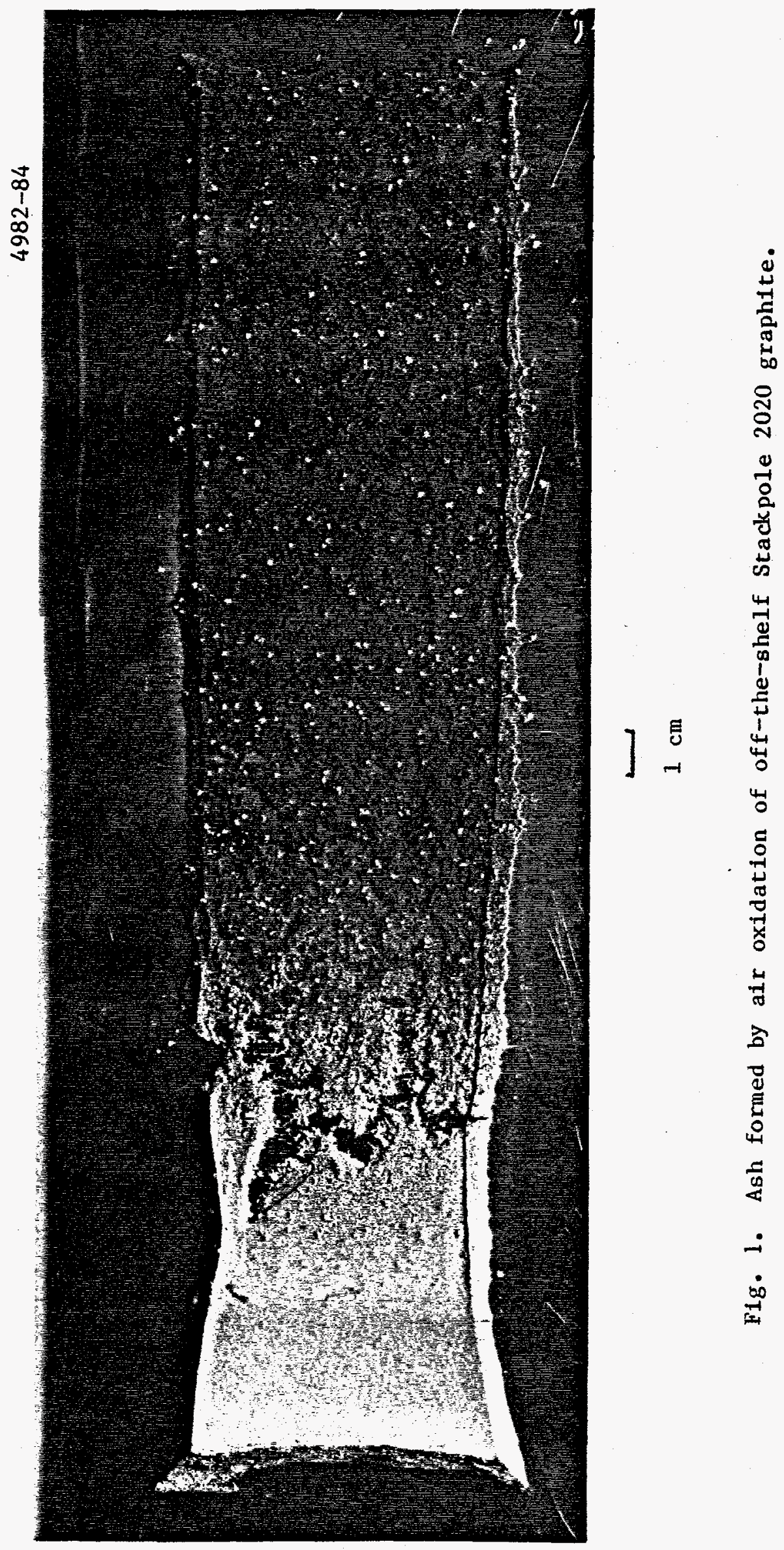


4361-84

\section{$\boldsymbol{\gamma}$}

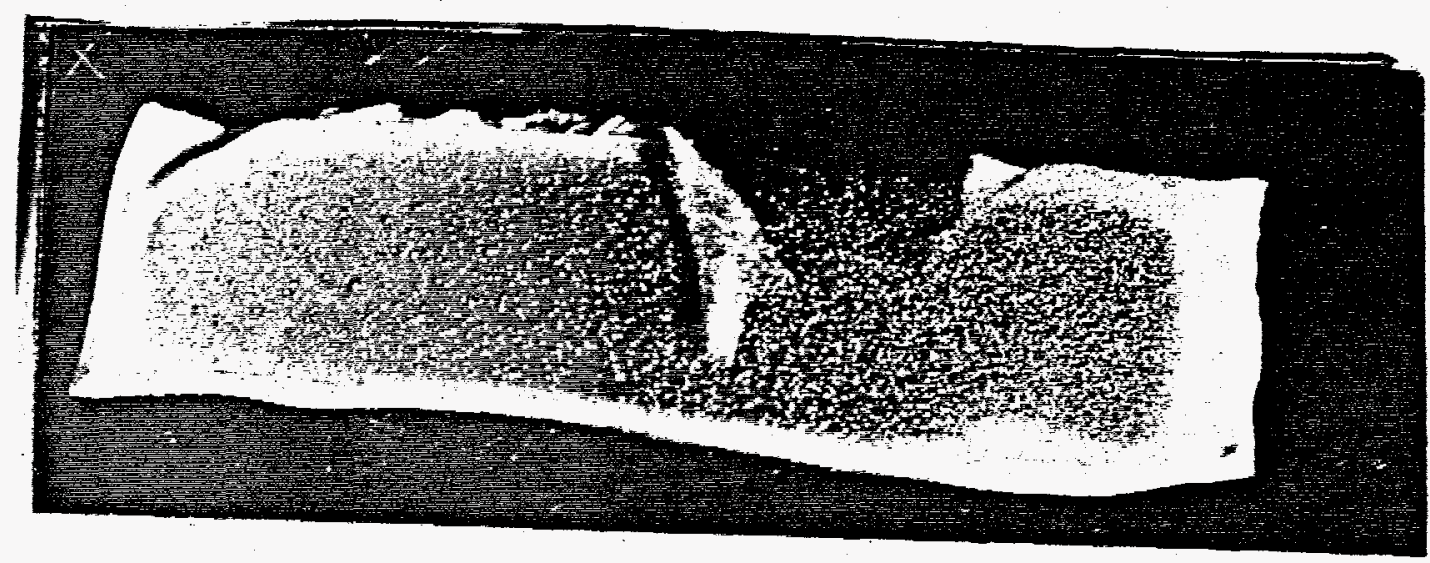

$1 \mathrm{~cm}$

Fig. 2. Ash formed by partial air oxidation of nuclear-quality Stackpole 2020 graphite. 
fibrous. Accordingly, only qualitative and descriptive references to the appearance of the ash are made.

Figure 2 shows a partially oxidized specimen of billet 24 , section C, quadrant IV, an internal section from lot 1. This figure illustrates the range of particle sizes referred to above and indicates the distribution of particles throughout the graphite.

Portions of the ash produced for these observations were subsequently examined using scanning electron microscopy and with energy dispersive $x$-ray analysis. The results are shown in Table 1 . These results are not calibrated to a standard and have only a relative significance. The uncertainties are estimated to be of the order of 10 to $20 \%$ of the specified value for those elements present in amounts of more than a few percent.

The table lists descriptions of different fields of view that were seen for each of the specimens 1isted. Because of the variation from field to field, qualitative phrases are used to refer to the different morphologies of the ash, e.g., particle, fines, plates, agglomerate, coarse material (relatively as compared with fine). Different parts of the billet produced ash that is described as being from the interior (near the billet axis), at the billet surface, or from an intermediate radius.

Small particles that are reported were of varied sizes and estimates of some of these sizes are also shown in the description column. Attention should be drawn to the agglomerate designation (always much larger than any entity referred to in the table as a particle).

Figure 3 shows an agglomerate particle from Stackpole 2020, off-theshelf graphite. The agglomerate specimen was analyzed at four different locations each encompassing a field of about $1 \mu^{2}$. The compositions in different parts of the particle included iron varying from 0 to $>40 \%$, little silicon, and varied amounts of aluminum, calcium, and sulfur.

Figure 4 shows an agglomerate particle from nuclear quality billet 30. The appearance is that of fine grained for fluffy type and, as shown 
Table 1. Energy dispersive $x$-ray analysis results for ash from selected Stackpole 2020 graphite specimens ${ }^{a}$

\begin{tabular}{|c|c|c|c|c|c|}
\hline \multirow{2}{*}{$\begin{array}{l}\text { Billet } \\
\text { No. }\end{array}$} & \multirow[b]{2}{*}{ Description } & \multicolumn{4}{|c|}{$\begin{array}{l}\text { Analysis } \\
\text { ent, assumed as oxide }\end{array}$} \\
\hline & & $\mathrm{Ca}$ & Si & $\mathrm{Fe}$ & Other elements \\
\hline \multirow[t]{3}{*}{220} & $\begin{array}{l}\text { Interior } \\
\text { particle } \\
\text { fines } \\
\text { plates }\end{array}$ & $\begin{array}{r}6.0 \\
22.0 \\
33.2\end{array}$ & $\begin{array}{r}4.7 \\
21.1 \\
9.1\end{array}$ & $\begin{array}{r}38.6 \\
7.1 \\
0.5\end{array}$ & $\begin{array}{l}\mathrm{Ti}, 14.5 ; \mathrm{V}, 1.1 \\
\mathrm{Cr}, 0.5 ; \mathrm{T} i, 4.8 ; \mathrm{V}, 2.2 \\
\mathrm{~S}, 12.0 ; \mathrm{A} 1,0.4\end{array}$ \\
\hline & $\begin{array}{l}\text { Intermediate } \\
\text { particle } \\
\text { overall, av }\end{array}$ & $\begin{array}{l}13.3 \\
16.1\end{array}$ & $\begin{array}{l}21.0 \\
20.5\end{array}$ & $\begin{array}{r}7.8 \\
15.5\end{array}$ & $\begin{array}{l}\mathrm{T} I, 1.5 ; \mathrm{V}, 0.8 ; \mathrm{Al}: 10.8 \\
\mathrm{~T} 1,4.2 ; \mathrm{V}, 1.7 ; \mathrm{A} 1,0.5\end{array}$ \\
\hline & $\begin{array}{l}\text { Surface } \\
\text { fines } \\
\text { fines } \\
\text { particle } \\
(3 \mu \mathrm{m}) \\
\text { plate }\end{array}$ & $\begin{array}{r}5.7 \\
8.7 \\
17.5 \\
9.6\end{array}$ & $\begin{array}{l}34.3 \\
30.1 \\
19.4 \\
31.1\end{array}$ & $\begin{array}{r}7.5 \\
9.4 \\
17.5 \\
9.3\end{array}$ & $\begin{array}{l}\mathrm{Ti}, 0.4 ; \mathrm{S}, 0.4 ; \mathrm{V}, 0.4 \\
\mathrm{Ti}, 0.7 ; \mathrm{S}, 0.3 ; \mathrm{V}, 0.6 \\
\mathrm{Ti}, 1.3 ; \mathrm{S}, 1.8 ; \mathrm{V}, 0.8 \\
\mathrm{Ti}, 1.3 ; \mathrm{S}, 0.6, \mathrm{~V}, 0.8\end{array}$ \\
\hline \multirow[t]{2}{*}{30} & $\begin{array}{l}\text { Interior } \\
\text { agglomerate } \\
\text { agglomerate } \\
\text { fines }\end{array}$ & $\begin{array}{l}28.1 \\
27.5 \\
35.5\end{array}$ & $\begin{array}{l}23.6 \\
26.8 \\
11.1\end{array}$ & $\begin{array}{l}2.4 \\
0.3 \\
2.5\end{array}$ & $\begin{array}{l}\mathrm{S}, 1.0 \\
\mathrm{Ti}, 0.7 \\
\mathrm{~A} 1,1.2 ; \mathrm{S}, 1.9 ; \mathrm{Ti}, 6.8\end{array}$ \\
\hline & $\begin{array}{l}\text { Surface } \\
\text { agglomerate } \\
\text { fines }\end{array}$ & $\begin{array}{l}24.0 \\
27.4\end{array}$ & $\begin{array}{l}23.9 \\
19.8\end{array}$ & & $\begin{array}{l}\mathrm{S}, 3.3 ; \mathrm{T} i, 1.3 \\
\mathrm{~S}, 6.0 ; \mathrm{T} i, 1.3\end{array}$ \\
\hline \multirow[t]{3}{*}{24} & $\begin{array}{l}\text { Interior } \\
\quad \text { agglomerate }\end{array}$ & 17.4 & 27.4 & 0.1 & $\mathrm{~S}, 3.4 ; \mathrm{Ti}, 1.3 ; \mathrm{V}, 0.5$ \\
\hline & $\begin{array}{l}\text { Intermediate } \\
\text { particles } \\
(20 \mu \mathrm{m}) \\
(40 \mu \mathrm{m})\end{array}$ & $\begin{array}{r}14.7 \\
4.0\end{array}$ & $\begin{array}{r}12.7 \\
3.0\end{array}$ & 0.2 & $\begin{array}{l}\mathrm{Ti}, 17.5 ; \mathrm{V}, 3.7 ; \mathrm{S}, 5.8 \\
\mathrm{Ti}, 45 ; \mathrm{V}, 10\end{array}$ \\
\hline & $\begin{array}{l}\text { Surface } \\
\text { fine } \\
\text { coarse }\end{array}$ & $\begin{array}{r}6.7 \\
20.7\end{array}$ & $\begin{array}{l}21.3 \\
18.2\end{array}$ & & $\begin{array}{ll}\mathrm{Ti}, & 27.4 \\
\mathrm{Ti} & 19.4\end{array}$ \\
\hline
\end{tabular}

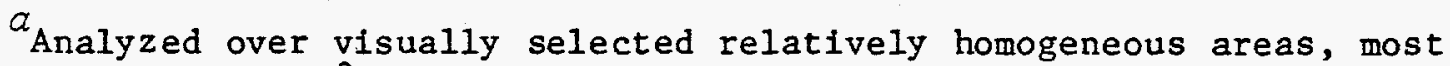
generally about $1 \mu \mathrm{m}^{2}$. 


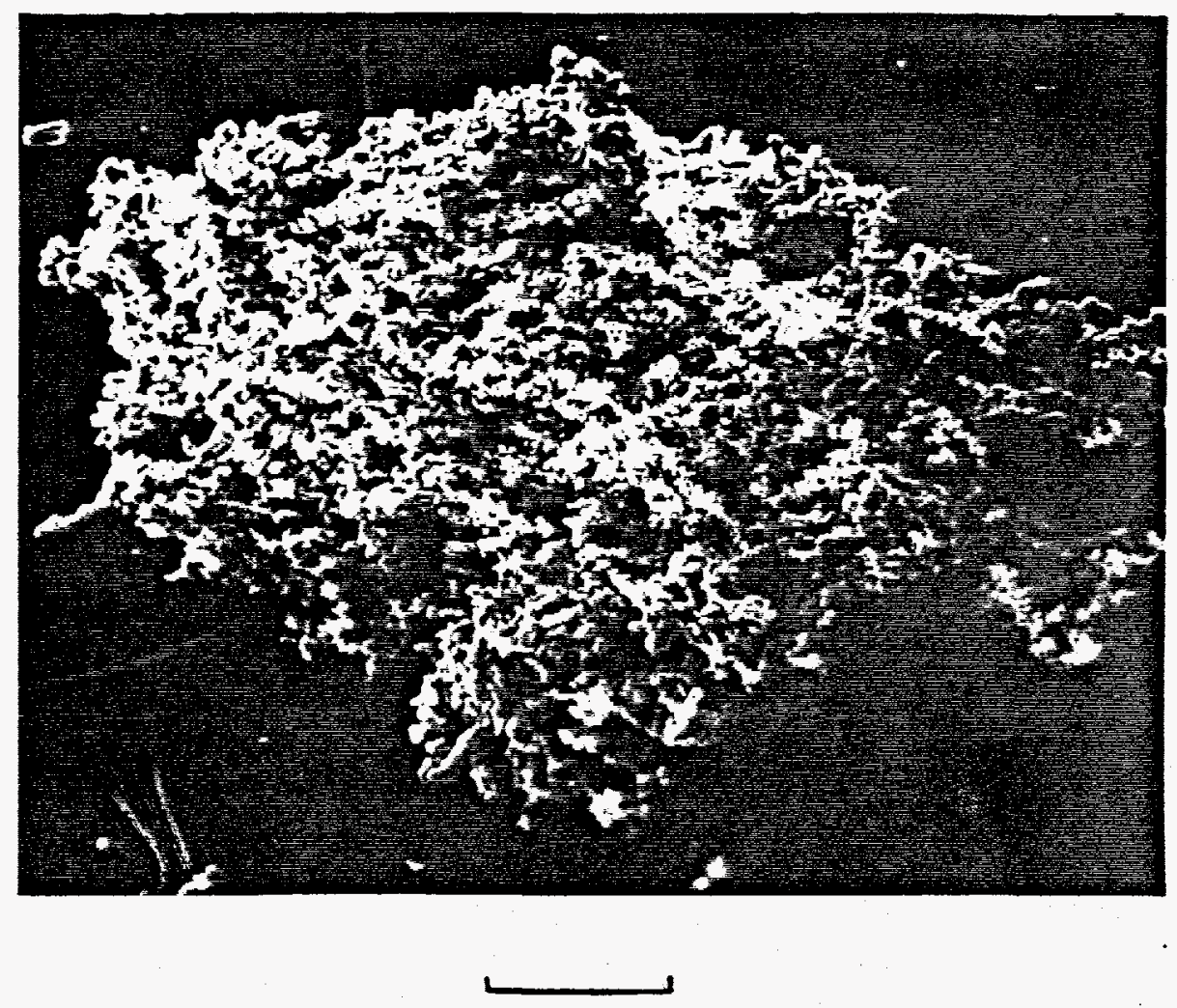

$0.01 \mathrm{~cm}$

Fig. 3. Agglomerate particle from off-the-shelf stackpole 2020 graphite. 
S-17565

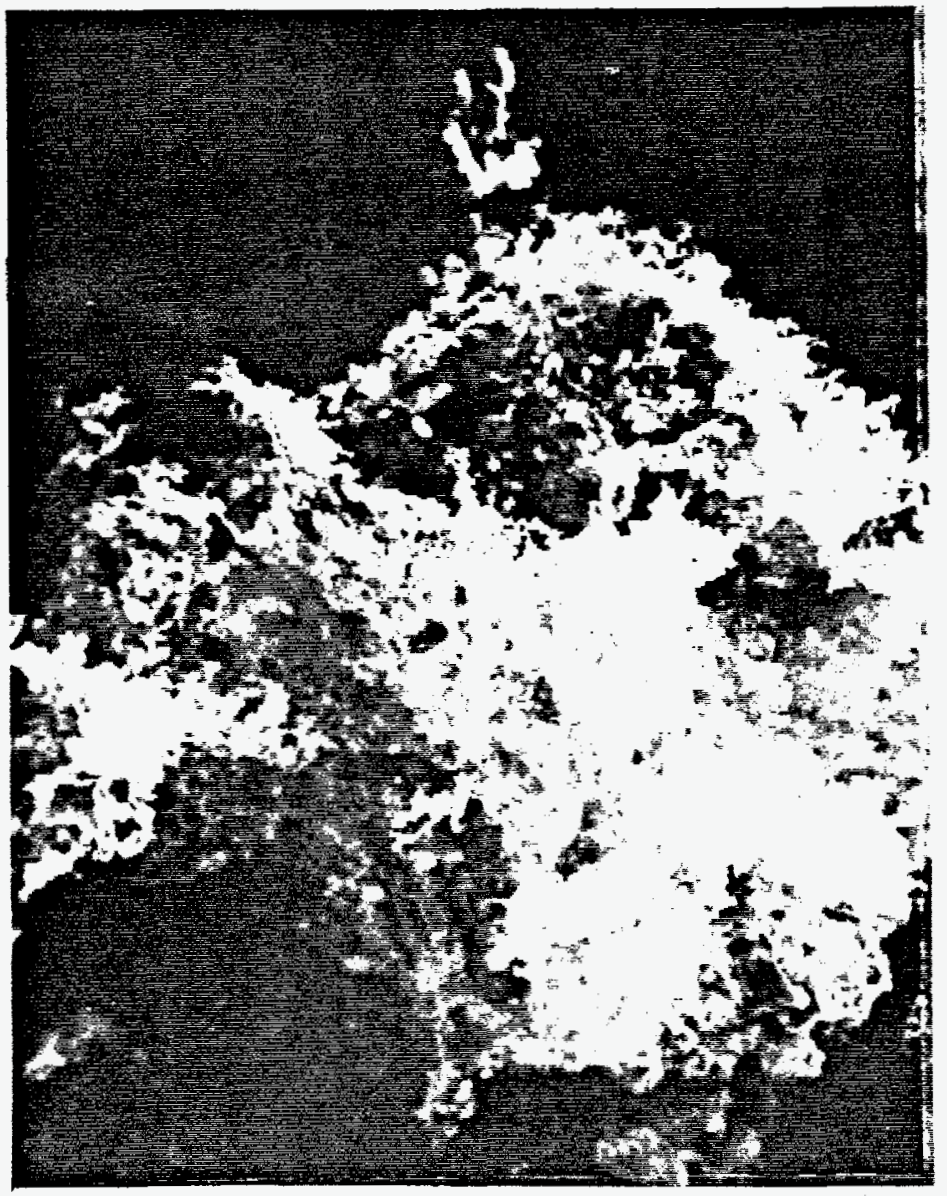

$$
0.01 \mathrm{~cm}
$$

Fig. 4. Agglomerate particle from nuclear-quality Stackpole 2020 graphite. 
in Table 1, contained little iron, no aluminum, and much more silicon. These differences could have resulted from the heat treatment given during the graphitization. The uniformity of the two analyses listed in Table 2 is noteworthy as indicating the possibility that the particles had become more homogeneous.

Table 2. Appearance of heat treated specimens of regraphitized nuclear grade Stackpole 2020

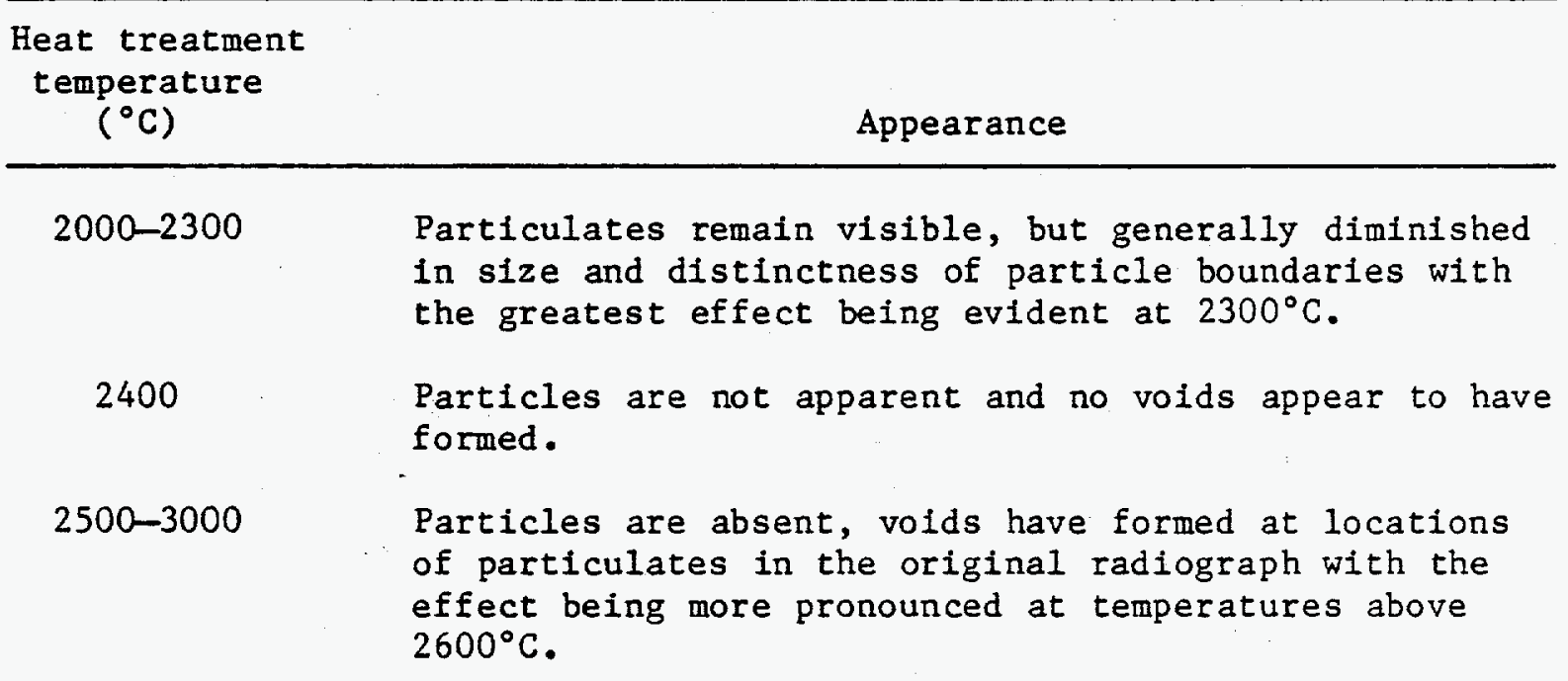

The marked variability of composition from point to point in ash specimens of such widely differing types is not surprising. Some small particles showed distinct crystallinity and were found to contain high concentrations of titanium and vanadium in the case of samples from billet 24. Crystals such as the plates observed in the specimen from billet 220 might have been calcium sulphate after oxidation. These, of course, are artifacts of a variable composition. These results are in general agreement with the results of chemical analysis, but obviously were not expected to reflect those results exactly.

HEAT TREATMENT STUDIES

A group of Stackpole 2020 graphite pieces from lot 2 were regraphitized by the manufacturer in an attempt to remove thermally particulate 
impurities found in the materials that had been received earlier. This regraphitization was supposedly performed at $>2600^{\circ} \mathrm{C}$, although we have reason to suspect this temperature was not attained. These graphite pleces were cylinders $48.3 \mathrm{~cm}$ (19 in.) long and $27 \mathrm{~cm}$ (11 in.) diameter. A sample was taken for radiographic examination and analysis. A $1 / 4 \mathrm{in}$. slice from the end of one cylinder was radiographed to observe whether the particulates of inorganic impurities present in the piece had been altered or removed by the reprocessing.

The sample was found to have numerous particulates. In order to assess the nature of these impurities, the slice was cut into 12 wedgeshaped pieces each of which was then thermally treated in a laboratory furnace in an argon atmosphere by heating rapidly to heat treatment temperatures between 2000 to $3000^{\circ} \mathrm{C}$ and held at the test temperature for $15 \mathrm{~min}$. Radiographic examination on the wedge-shaped specimens was made.

All of the specimens were affected by the heat treatment. Table 2 lists the descriptions of the specimen radiographs as compared with radiographs of the same material prior to the heat treatment.

It is particularly worth noting that for the specimens heated to above $2500^{\circ} \mathrm{C}$, voids formed at locations of particulates in the original material. Chemical analyses of the pieces were being conducted. Ash contents for some of them were determined and are shown in Table 3 . The chemical analyses, however, were inconclusive due to the small sample size.

Table 3. Ash contents for heat treated specimens of 2020

\section{Heat treatment temperature $\left({ }^{\circ} \mathrm{C}\right)$}

\begin{tabular}{cc}
\multicolumn{2}{c}{ Ash \% by weight } \\
\cline { 2 - 3 } $\begin{array}{c}\text { Specimen 1 } \\
(\text { wt } 8 \mathrm{~g})\end{array}$ & $\begin{array}{l}\text { Specimen 2 } \\
(\text { wt 3-4 g) }\end{array}$ \\
\hline 0.094 & 0.147 \\
0.035 & 0.038 \\
0.020 & 0.040 \\
0.014 & 0.029 \\
0.003 & 0.024 \\
0.008 & 0.016 \\
0.007 & 0.017 \\
0.069 & 0.147
\end{tabular}


The radiographic data and the ash analyses show that at heat treatment temperatures as $10 \mathrm{w}$ as $2400^{\circ} \mathrm{C}$, a distinct decrease in impurities occurred.

Calculations and reference melting point data were compiled of vapor pressures or metals in equilibrium with either the metal or the carbides as appropriate. (For oxide particulates in contact with graphite, conversion to the carbide is favored.) The results of these calculations are shown in Fig. 5.

It is clear that at temperatures of $2400^{\circ} \mathrm{C}$, many of the carbides [viz. $\mathrm{Al}_{4} \mathrm{C}_{3}, \mathrm{CaC}_{2}$, and $\mathrm{Fe}_{3} \mathrm{C}$ ] are melted. It is expected that lower melting eutectics or other compositions might have formed at lower heat treatment temperatures. Because calcium has a high vapor pressure even below $2000^{\circ} \mathrm{C}$, vaporization of both $\mathrm{Ca}$ and $\mathrm{Al}$ could occur from the solid but probably at lower rates than from the liquid. Alteration of the particulates at the lower heat treatment temperatures would be expected to occur. Silicon, titanium, and iron would require higher temperatures for removal as judged by these vapor pressure curves.

Upon rapid heating to higher temperatures than $2400^{\circ} \mathrm{C}$ in these studies, it is quite possible that the carbides melted and were expelled without as much decomposition to carbon thus creating the voids, while at lower temperatures, a portion of the metals evaporated leaving a residue of carbon. This would have produced the more uniform appearance of the radiograph of the specimen heated to and held at $2400^{\circ} \mathrm{C}$.

A final set of heat treatment studies in cooperation with Stackpole is in progress using their Acheson furnaces.

\section{DISCUSSION AND CONCLUSION}

Particles have been historically found in 2020 off-the-shelf graphite. These particles had been expected and assumed to be iron that is added intentionally in the manufacturing process (as a puffing inhibitor), as wear dust from grinding, milling, and other operations, or as rust from handling equipment. 


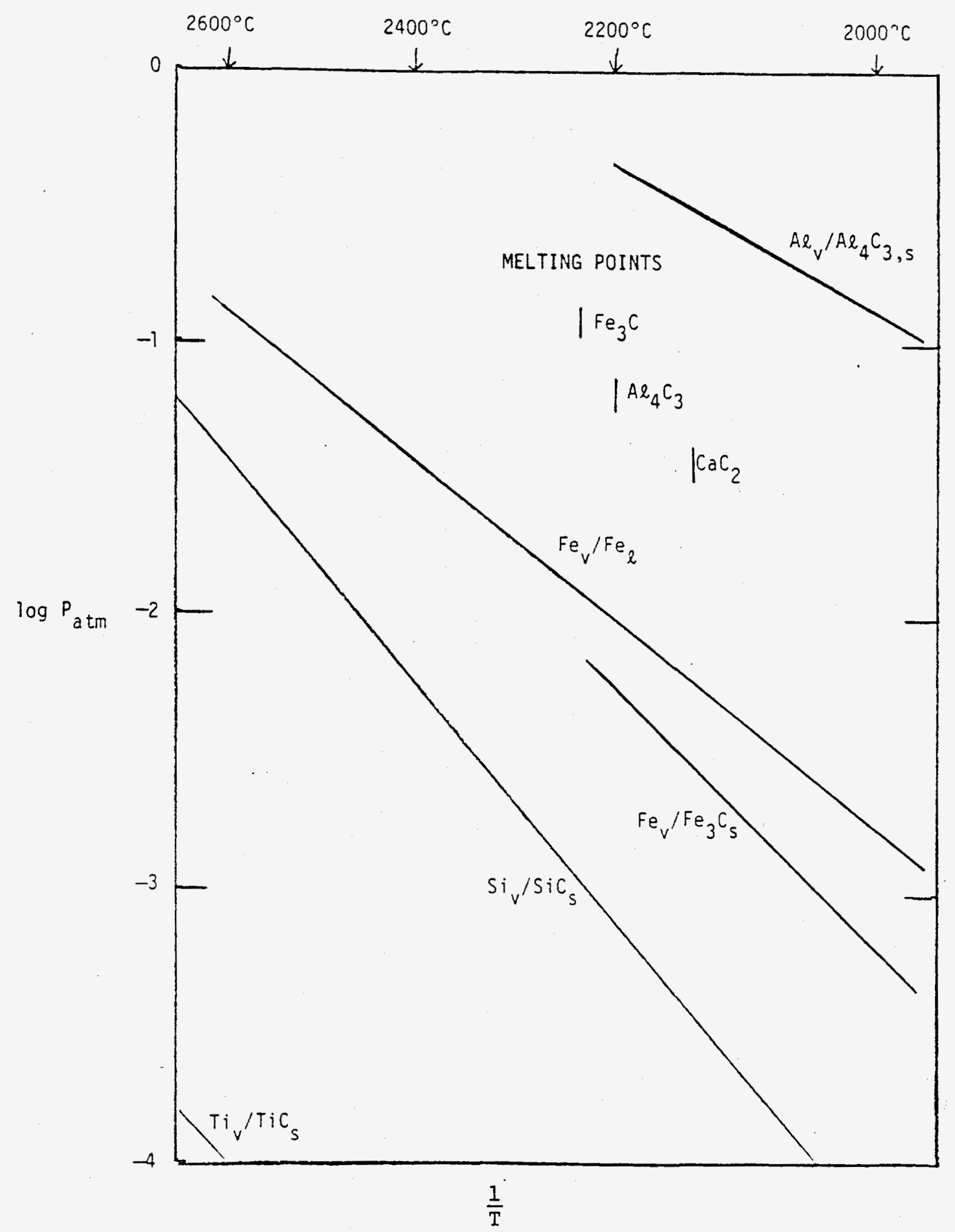

Fig. 5. Calculated vapor pressures of metals in equilibrium with their carbides; melting points for three carbides are indicated. 
When the particles were found in nuclear quality graphite that had very low iron contents, the analysis plan described in this report was designed and conducted. The finding of principal impurity levels of calcium and silicon led to the assumption that somehow, the graphitization furnace or the graphitizing process was responsible.

Some tests were run in cooperation with the Stackpole Company. These studies resulted in the recognition that:

1. the impurities were not simply iron,

2. they were not due to the graphitization process, and

3. their clay-1ike character suggested their early introduction.

The findings were communicated to the Stackpole Co. Their staff was able to localize the source and to design a process change that is believed to be able to eliminate these impurities from future lots of material. The cause hase been communicated to the author and W. P. Eatherly on a proprietary basis and we concur with their analysis of the problem. Inproved lots of 2020 are now being scheduled and will be investigated by the Atomic Vapor Laser Isotope Separation (AVLIS) program.

\section{ACKNOWLEDGMENTS}

Discussions with and the insights communicated by W. P. Eatherly are gratefully acknowledged. The help of Daniel A. Smith and William A. Nystrom of the Stackpole Company are also greatly appreciated. Especially to be noted was their cooperation and willingness to conduct experiments both jointly with us and experiments conducted solely at the Stackpole Corporation. The skilled analytical capabilities of C. S. Macdougall of the ORNL Analytical Chemistry Division played an important part in this work. Also acknowledge here are the assistance of $C$. R. Kennedy and F. P. Jeffers of the Metals and Ceramics Division for the additional exploratory heat treatments conducted as part of this work. 
REFERENCES

1. J. P. Sanders and A. G. Grinde11, "HTR Component Flow Test Loop Studies," pp. 23-91 in High Temperature Gas-Cooled Reactor Technology Development Report for the Period Ending December 31, 1983, ORNL-6053, June 1984.

2. R. A. Strehlow and H. C. Young, Summary of Results of Test Zero Phase Two of the Core Support Performance Test Series, ORNL/GCR-84/6, August 1984.

3. R. A. Strehlow and W. P. Eatherly, Interim Report on Chemical Studies of Stackpole 2020 Graphite, ORNL/GCR-84/13, September 1985.

4. R. A. Strehlow and W. P. Eatherly, op. cit. Appendix B, p. 3. 